\title{
Effects of ganglioside GM1 and neural growth factor on neural stem cell proliferation and differentiation
}

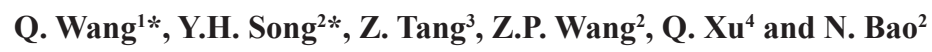 \\ ${ }^{1}$ Pediatric Department, Shanghai First People's Hospital, Shanghai, China \\ ${ }^{2}$ Neurosurgery Department, \\ Shanghai Children's Medical Center Affiliated to Shanghai Jiaotong \\ University School of Medicine, Shanghai, China \\ ${ }^{3}$ College of Mechanical Engineering, Donghua University, Shanghai, China \\ ${ }^{4}$ Scientific Research Center, Shanghai Xinhua Hospital, Shanghai, China \\ *These authors contributed equally to this study. \\ Corresponding author: N. Bao \\ E-mail: baonansh@sina.com
}

Genet. Mol. Res. 15 (3): gmr.15038376

Received January 4, 2016

Accepted March 11, 2016

Published August 5, 2016

DOI http://dx.doi.org/10.4238/gmr.15038376

Copyright (C) 2016 The Authors. This is an open-access article distributed under the terms of the Creative Commons Attribution ShareAlike (CC BY-SA) 4.0 License.

\begin{abstract}
Neurogenesis, recovery from nerve injury, neurodegeneration, and Parkinson's disease affect people's health, yet the underlying molecular mechanisms remain elusive. Here, we investigated the effect of ganglioside GM1 and neural growth factor (NGF) on neural stem cell (NSC) proliferation and differentiation in vitro to provide a scientific basis for comprehensive treatment of nervous system diseases via NSC application. As widely applied methods of relatively high accuracy, cell counts and 3-(4,5-dimethyl2-thiazolyl)-2,5-diphenyl-2-H-tetrazolium bromide (MTT) assays were used to assess NSC proliferation. In addition, western blotting
\end{abstract}


was employed to determine NSC differentiation. Cell counts and MTT assays demonstrated that in epidermal growth factor (EGF)and basic fibroblast growth factor (bFGF)-containing medium, a high concentration of GM1, but not NGF, significantly elevated NSC proliferation. In NSC cultures lacking EGF and bFGF, cell counts and MTT values were significantly increased compared to those in the negative control group on days 4, 7, and 10 after GM1 $(25,100$, and 200 $\mathrm{ng} / \mathrm{mL})$ but not NGF $(25,50,100$, and $200 \mathrm{ng} / \mathrm{mL})$ treatment. Western blotting revealed significantly increased expression of nestin (an NSC marker) in NSCs treated with GM1, and upregulation of glial fibrillary acidic protein (a glial cell marker) and neuron-specific enolase (a neuron marker) in those administered NGF. Our results suggest that GM1 and NGF induce NSC proliferation and differentiation, respectively, in a dose-dependent manner.

Key words: Neural stem cell; Proliferation; Differentiation; Ganglioside GM1; Neural growth factor

\section{INTRODUCTION}

The concept of neural stem cells (NSCs) was first put forward in the 1990s (Reynolds and Weiss, 1992). These cells have been shown to proliferate while maintaining the ability to differentiate, and are capable of surviving, integrating, and differentiating in the nervous tissues of hosts after transplantation, providing the necessary and sufficient basis for NSC therapy (Corti et al., 2003).

In the embryonic and early postnatal murine brain, NSCs generate neurons and glia (Götz and Huttner, 2005; Paridaen and Huttner, 2014). Recently, these cells were also found to be able to differentiate into neurons, astrocytes, and oligodendrocytes after isolation and amplification in vitro (Ji et al., 2014). The use of NSCs has been proposed as a potential treatment for nerve injury, neurodegeneration, and Parkinson's disease, among other neurogenesis-related conditions (Ourednik et al., 2000).

At the onset of neurogenesis, neural progenitors first divide symmetrically to expand their numbers, before switching to asymmetric neurogenic division. The molecular mechanisms controlling neurogenesis have been extensively studied. Currently, we have a broad comprehension of the intrinsic factors and extracellular signaling pathways effectively driving proliferation and differentiation of NSCs (Burney et al., 2013; Urbán and Guillemot, 2014). Gene expression is principally regulated by internal factors, while the cellular microenvironment is dominated by external influences. Notch, $\gamma$-aminobutyric acid, Wnt, insulin growth factors (IGFs), and sonic hedgehog are known to modulate the rate of neurogenesis in the adult dentate gyrus (Ming and Song, 2011; Faigle and Song, 2013). However, owing to the limitations of in vivo studies, little is known of the mechanisms by which these signals exert their effects.

As common trophic neurological drugs, ganglioside GM1 and neural growth factor (NGF) are widely used in clinical settings. Animal experiments have demonstrated that GM1 and NGF may have a synergistic effect on neuron proliferation and differentiation (Itokazu et al., 2013; Chen et al., 2014). To date, increasing evidence has shown the importance of spinal

Genetics and Molecular Research 15 (3): gmr.15038376 
cord-derived NSCs. The current study aimed to investigate the effect of high GM1 and NGF concentrations on NSC proliferation and differentiation in vitro, and determine their effective doses to provide a scientific basis for comprehensive treatment of nervous system diseases via NSC application.

\section{MATERIAL AND METHODS}

\section{Materials}

The following reagents were used in our study: Dulbecco's modified Eagle's medium (DMEM)/F12, B-27 and N-2 supplements, trypsin, fetal bovine serum (FBS), poly-D-lysine, mouse anti-neuron-specific enolase (NSE) antibody, mouse anti-glial fibrillary acidic protein (GFAP) antibody (Gibco, Waltham, MA, USA), basic fibroblast growth factor (bFGF), epidermal growth factor (EGF; Sigma-Aldrich, St. Louis, MI, USA), NGF (Invitrogen, Carlsbad, CA, USA), GM1 (TRB pharmaceuticals, Vouvry, Switzerland), and mouse antinestin antibody (Genetimes, Hong Kong, China).

\section{Animal husbandry and ethics statement}

All experiments were performed on four-week-old adult Sprague-Dawley (SD) rats, weighing 220-240 g, provided by the Shanghai Experimental Animal Center of the Chinese Academy of Sciences. Forty-six rats (at a 1:1 female to male ratio) were housed under pathogen-free conditions at a controlled temperature $\left(24 \pm 1{ }^{\circ} \mathrm{C}\right)$ with a $12: 12$-h light-dark cycle. Males and females were fed in a single cage, and vaginal smear tests were carried out the next morning. Sixteen of the 23 female SD rats were found to be pregnant, and at embryonic day 13 , were anesthetized with sodium pentobarbital $(100 \mathrm{mg} / \mathrm{kg})$, then killed by cervical dislocation and randomly divided into four groups. Each embryo was removed under rigorously sterile conditions. The spinal cords of three embryos from each pregnant SD rat were removed under a dissecting microscope and placed in a centrifuge tube supplemented with DMEM. These were further separated into five to seven different treatment groups (depending on the experiment), as shown in Tables 1-4. All animal welfare standards and experimental procedures complied with the National Institutes of Health Guide for the Care and Use of Laboratory Animals and were approved by the Animal Ethics Committee of the Shanghai Jiaotong University School of Medicine.

\section{Primary cultures of rat fetal spinal cord NSCs}

Rat fetal spinal cord was cut into 0.5-1-mm blocks using ophthalmic scissors, and digested in $5 \mathrm{~mL} 0.125 \%$ trypsin $(\mathrm{w} / \mathrm{v})$ at $37^{\circ} \mathrm{C}$ for $10 \mathrm{~min}$. The tissue was subsequently separated thoroughly by straw blow and neutralized with phosphate-buffered saline-Tween 20 (PBS-T), $\mathrm{pH}$ 7.2-7.4, containing 10\% FBS. This cell suspension was centrifuged and rinsed three times with $5 \mathrm{~mL}$ PBS-G, before finally being transferred to DMEM/F12 containing 2 $\mathrm{mM}$ glutamine, $1 \%$ penicillin, and $1 \%$ streptomycin. Cells were adjusted to a concentration of $1 \times 10^{6} / \mathrm{mL}$ by virtue of a trypan blue stain assay, administered $2 \% \mathrm{~B}-27,20 \mathrm{ng} / \mathrm{mL}$ EGF, and $20 \mathrm{ng} / \mathrm{mL}$ bFGF, seeded on a $6-\mathrm{cm}$ culture dish, and cultured at $37^{\circ} \mathrm{C}$ in a $5 \% \mathrm{CO}_{2}$ incubator for 7 days. Half of the culture medium was changed every 2-3 days.

Genetics and Molecular Research 15 (3): gmr.15038376 


\section{Isolation and passage of NSCs}

Primary NSC cultures were centrifuged at $600 \mathrm{~g}$ for $8 \mathrm{~min}$, and digested with $0.125 \%$ trypsin at $37^{\circ} \mathrm{C}$ in a $5 \% \mathrm{CO}_{2}$ incubator for 5 min. Digestion was terminated with $10 \% \mathrm{FBS}$, before a further centrifugation at $600 \mathrm{~g}$ for $10 \mathrm{~min}$. Supernatant was discarded and N-2 culture solution was added to obtain a cell suspension. Cells were then seeded and cultured on a $6-\mathrm{cm}$ culture plate for 7 days, with half of the culture medium being changed every 2-3 days.

\section{Investigation of the effects of GM1 and NGF on NSC proliferation in DMEM/F12 containing bFGF and EGF}

NSCs were cultured at a density of $1 \times 10^{5} / \mathrm{mL}$ on 96 -well plates, with $100 \mu \mathrm{L}$ in each well. The experiment comprised positive control (NSC medium containing EGF and bFGF), NGF $(25,50,100$, and $200 \mathrm{ng} / \mathrm{mL})$, GM1 $(10,25,100,200 \mathrm{ng} / \mathrm{mL})$, and NGF+GM1 (100 $\mathrm{ng} / \mathrm{mL}$ NGF and $100 \mathrm{ng} / \mathrm{mL}$ GM1) groups. Four wells were used for each group, and cells were cultured at $37^{\circ} \mathrm{C}$ in a $5 \% \mathrm{CO}_{2}$ atmosphere. Cells were observed with a phase contrast microscope, and 3-(4,5-dimethyl-2-thiazolyl)-2,5-diphenyl-2H-tetrazolium bromide (MTT) assays were conducted on days 4, 7, and 10. Each experiment was performed four times.

\section{Assessment of the influence of GM1 and NGF on NSC proliferation in DMEM/F12 lacking bFGF and EGF}

NSCs were seeded at a density of $1 \times 10^{5} / \mathrm{mL}$ on 96-well plates, with $100 \mu \mathrm{L}$ in each well. The experiment was divided into negative control (DMEM/F12 lacking EGF and bFGF), NGF $(25,50,100$, and $200 \mathrm{ng} / \mathrm{mL})$, GM1 $(10,25,100$, and $200 \mathrm{ng} / \mathrm{mL})$, and NGF+GM1 groups (100 $\mathrm{ng} / \mathrm{mL} \mathrm{NGF}$ and $100 \mathrm{ng} / \mathrm{mL}$ GM1). Each group comprised four wells, and cells were cultured at $37^{\circ} \mathrm{C}$ in a $5 \% \mathrm{CO}_{2}$ atmosphere. Cells were observed by phase contrast microscopy, and MTT assays were conducted on days 4, 7, and 10. Each experiment was performed four times.

\section{Western blot}

In groups with culture medium containing EGF and bFGF, expression of nestin, NSE, and GFAP was evaluated by western blotting after administration of GM1 and NGF on Days 4 and 7. NSCs were seeded at a density of $1 \times 10^{5} / \mathrm{mL}$ on 96 -well plates, $100 \mu \mathrm{L}$ in each well, and cultured at $37^{\circ} \mathrm{C}$ in a $5 \% \mathrm{CO}_{2}$ incubator before being collected on days 4 and 7 . Cell lysates were prepared using radio immunoprecipitation assay lysis buffer (Beyotime Biotechnology, Shanghai, China) containing a protease/phosphatase inhibitor cocktail (Cell Signaling Technology, Beverly, MA, USA). In brief, the quantity of protein lysate was measured with a bicinchoninic acid assay and standardized across samples. Proteins were separated by sodium dodecyl sulfate-polyacrylamide gel electrophoresis and transferred to polyvinylidene fluoride membranes. Membranes were blocked in 5\% skim milk at room temperature for $1 \mathrm{~h}$ and immunoblotted with primary antibodies (anti-nestin, -NSE, and -GFAP; all 1:1000) at $4^{\circ} \mathrm{C}$ overnight. After being washed with Tris-buffered saline-Tween 20, membranes were incubated with the corresponding horseradish peroxidase-conjugated secondary antibodies for $1 \mathrm{~h}$ at room temperature. Blots were developed with SuperSignal West Femto Maximum Sensitivity 
Substrate (Pierce/Thermo Scientiðc, Rockford, IL, USA), and images were obtained using an ImageQuant LAS 4000 (GE Healthcare, Little Chalfont, UK). As a loading control, an anti$\alpha$-tubulin antibody (1:5000) was used. Experiments were repeated four times.

\section{MTT assays}

MTT assays were performed to examine cell proliferation. Approximately $5 \times 10^{3}$ cells were seeded into each well of 96-well plates. To each well, $10 \mu \mathrm{L}$ MTT reagent was added, and the plate was incubated at $37^{\circ} \mathrm{C}$ for $4 \mathrm{~h}$. Wells were then washed with PBS and dried for approximately $4 \mathrm{~h}$, before $150 \mu \mathrm{L}$ dimethyl sulfoxide was added to them. The microtiter plate was placed on a shaker to dissolve the dye. Absorbance was then recorded at $490 \mathrm{~nm}$ using a Bio-Rad (Hercules, CA, USA) iMark plate reader.

\section{Statistical analysis}

SPSS 17.0 (SPSS Inc., Chicago, IL, USA) was employed for data analysis, and data are reported as means \pm standard error of the mean. Two-factor analysis of variance was utilized for comparisons between groups, while the least significant difference method was applied in pairwise comparisons. $\mathrm{P}<0.05$ represented a statistically significant difference.

\section{RESULTS}

\section{NSC count and viability under different GM1 concentrations in medium containing bFGF and EGF}

NSC culture medium containing bFGF and EGF acted as a bFGF+EGF control. In each group, both cell counts and MTT assay values increased in a time-dependent manner from day 4 to day 10 after GM1 administration. Moreover, compared with the positive control group, cell counts and MTT values in groups treated with 25, 100, and $200 \mathrm{ng} / \mathrm{mL} \mathrm{GM1}$ were significantly increased $(\mathrm{P}<0.05)$ on days 7 and 10 . These measurements were also significantly elevated $(\mathrm{P}<0.05)$ on day 4 in cells treated with the higher GM1 doses $(100$ and $200 \mathrm{ng} / \mathrm{mL})$, whereas the lowest concentration $(10 \mathrm{ng} / \mathrm{mL})$ displayed no significant effects $(\mathrm{P}$ $>0.05$ ) over the course of the experiment. Administration of $25 \mathrm{ng} / \mathrm{mL}$ GM1 resulted in no significant changes $(\mathrm{P}>0.05)$ to cell count or MTT value on day 4 compared with the control group, as shown in Table 1.

Table 1. Cell count and viability at Days 4, 7, and 10 following ganglioside GM1 administration in basic fibroblast growth factor- and epidermal growth factor-containing medium $(\mathrm{N}=4$, data are reported as means \pm standard error).

\begin{tabular}{l|c|c|c|c|c|c}
\hline \multirow{2}{*}{ Group } & \multicolumn{2}{|c|}{ Day 4} & \multicolumn{2}{c|}{ Day 7} & \multicolumn{2}{c}{ Day 10 } \\
\cline { 2 - 7 } & Cell count & MTT value & Cell count & MTT value & Cell count & MTT value \\
\hline EGF+bFGF $(C)$ & $31.3 \pm 2.2$ & $0.117 \pm 0.004$ & $50.7 \pm 3.1$ & $0.132 \pm 0.002$ & $63.5 \pm 1.3$ & $0.161 \pm 0.004$ \\
\hline GM1 $(10 \mathrm{ng} / \mathrm{mL})+\mathrm{C}$ & $30.5 \pm 1.9$ & $0.117 \pm 0.001$ & $53.0 \pm 1.4$ & $0.135 \pm 0.002$ & $65.5 \pm 2.4$ & $0.166 \pm 0.001$ \\
\hline GM1 $(25 \mathrm{ng} / \mathrm{mL})+\mathrm{C}$ & $34.3 \pm 1.7$ & $0.123 \pm 0.002$ & $63.5 \pm 1.9^{*}$ & $0.141 \pm 0.003^{*}$ & $76.0 \pm 0.8^{*}$ & $0.209 \pm 0.012^{*}$ \\
\hline GM1 $(100 \mathrm{ng} / \mathrm{mL})+\mathrm{C}$ & $42.5 \pm 3.4^{*}$ & $0.127 \pm 0.002^{*}$ & $70.3 \pm 1.3^{*}$ & $0.156 \pm 0.001^{*}$ & $77.8 \pm 2.2^{*}$ & $0.221 \pm 0.008^{*}$ \\
\hline GM1 $(200 \mathrm{ng} / \mathrm{mL})+\mathrm{C}$ & $44.0 \pm 3.9^{*}$ & $0.128 \pm 0.002^{*}$ & $71.8 \pm 4.3^{*}$ & $0.160 \pm 0.002^{*}$ & $79.5 \pm 2.4^{*}$ & $0.237 \pm 0.007^{*}$ \\
\hline
\end{tabular}

$* \mathrm{P}<0.05$ vs EGF+bFGF (C) group. bFGF = basic fibroblast growth factor; EGF = epidermal growth factor; MTT

= 3-(4,5-dimethyl-2-thiazolyl)-2,5-diphenyl-2H-tetrazolium bromide. 


\section{NSC count and viability under different NGF concentrations in medium containing bFGF and EGF}

NSC culture medium containing bFGF and EGF served as a bFGF+EGF control. None of the NGF concentrations used exerted a significant effect $(\mathrm{P}>0.05)$ on either cell count or cell viability compared with the positive control group. Moreover, co-treatment with high concentrations of GM1 $(100 \mathrm{ng} / \mathrm{mL})$ and NGF $(100 \mathrm{ng} / \mathrm{mL})$ had no notable influence $(\mathrm{P}>$ 0.05 ) on these measurements in comparison with the positive control, as displayed in Table 2.

Table 2. Cell count and viability at days 4,7 , and 10 following neural growth factor administration in basic fibroblast growth factor- and epidermal growth factor-containing medium $(\mathrm{N}=4$, data are reported as means \pm standard error).

\begin{tabular}{l|c|c|c|c|c|c}
\hline \multirow{2}{*}{ Group } & \multicolumn{2}{|c|}{ Day 4} & \multicolumn{2}{c|}{ Day 7 } & \multicolumn{2}{c}{ Day 10 } \\
\cline { 2 - 7 } & Cell count & MTT value & Cell count & MTT value & Cell count & MTT value \\
\hline EGF+bFGF $(\mathrm{C})$ & $31.3 \pm 2.2$ & $0.117 \pm 0.004$ & $50.7 \pm 3.1$ & $0.132 \pm 0.002$ & $63.5 \pm 1.3$ & $0.161 \pm 0.004$ \\
\hline NGF $(25 \mathrm{ng} / \mathrm{mL})+\mathrm{C}$ & $28.0 \pm 1.8$ & $0.115 \pm 0.002$ & $47.0 \pm 2.9$ & $0.129 \pm 0.001$ & $60.8 \pm 2.2$ & $0.158 \pm 0.001$ \\
\hline NGF $(50 \mathrm{ng} / \mathrm{mL})+\mathrm{C}$ & $29.5 \pm 1.9$ & $0.116 \pm 0.002$ & $47.8 \pm 1.7$ & $0.127 \pm 0.002$ & $60.8 \pm 2.1$ & $0.159 \pm 0.001$ \\
\hline NGF $(100 \mathrm{ng} / \mathrm{mL})+\mathrm{C}$ & $29.0 \pm 1.8$ & $0.115 \pm 0.001$ & $51.0 \pm 1.8$ & $0.128 \pm 0.002$ & $60.3 \pm 1.0$ & $0.159 \pm 0.002$ \\
\hline NGF $(200 \mathrm{ng} / \mathrm{mL})+\mathrm{C}$ & $28.0 \pm 0.8$ & $0.113 \pm 0.002$ & $50.3 \pm 1.7$ & $0.124 \pm 0.002$ & $63.8 \pm 2.6$ & $0.161 \pm 0.001$ \\
\hline GM1+NGF+C & $32.0 \pm 0.8$ & $0.119 \pm 0.001$ & $53.0 \pm 2.6$ & $0.136 \pm 0.003$ & $63.0 \pm 1.8$ & $0.164 \pm 0.004$ \\
\hline
\end{tabular}

$\mathrm{NGF}=$ neural growth factor; bFGF = basic fibroblast growth factor; EGF = epidermal growth factor; MTT = 3-(4,5-dimethyl-2-thiazolyl)-2,5-diphenyl-2H-tetrazolium bromide.

\section{NSC count and viability under different GM1 concentrations in medium lacking bFGF and EGF}

In culture medium supplemented with neither bFGF nor EGF, at Days 4, 7, and 10 after treatment with 25,100 , and $200 \mathrm{ng} / \mathrm{mL} \mathrm{GM1}$, cell counts and MTT values were significantly increased in comparison with the negative $(\mathrm{P}<0.05)$, but not the positive control group $(\mathrm{P}>$ $0.05)$. However, the lowest GM1 dose $(10 \mathrm{ng} / \mathrm{mL})$ resulted in significantly reduced cell counts and MTT values compared with the positive $(\mathrm{P}<0.05)$ but not the negative $(\mathrm{P}>0.05)$ control on Days 4, 7, and 10 (Table 3).

Table 3. Cell count and viability at days 4,7 , and 10 following GM1 administration in medium lacking basic fibroblast growth factor and epidermal growth factor $(\mathrm{N}=4$, data are reported as means \pm standard error).

\begin{tabular}{l|c|c|c|c|c|c}
\hline \multirow{2}{*}{ Group } & \multicolumn{2}{|c|}{ Day 4} & \multicolumn{2}{c|}{ Day 7} & \multicolumn{2}{c}{ Day 10 } \\
\cline { 2 - 7 } & Cell count & MTT value & Cell count & MTT value & Cell count & MTT value \\
\hline EGF+bFGF $(\mathrm{C})$ & $53.8 \pm 3.4$ & $0.136 \pm 0.005$ & $65.5 \pm 1.3$ & $0.169 \pm 0.002$ & $72.8 \pm 3.7$ & $0.178 \pm 0.002$ \\
\hline GM1 $(10 \mathrm{ng} / \mathrm{mL})$ & $31.8 \pm 2.8^{*}$ & $0.122 \pm 0.003^{*}$ & $49.3 \pm 1.0^{*}$ & $0.161 \pm 0.002^{*}$ & $43.8 \pm 2.6^{*}$ & $0.158 \pm 0.002^{*}$ \\
\hline GM1 $(25 \mathrm{ng} / \mathrm{mL})$ & $51.0 \pm 1.4^{* *}$ & $0.132 \pm 0.002^{* *}$ & $61.8 \pm 3.0^{* *}$ & $0.166 \pm 0.004^{* *}$ & $70.5 \pm 1.3^{* *}$ & $0.175 \pm 0.002^{* *}$ \\
\hline GM1 $(100 \mathrm{ng} / \mathrm{mL})$ & $54.8 \pm 1.7^{* *}$ & $0.135 \pm 0.002^{* *}$ & $64.5 \pm 1.3^{* *}$ & $0.167 \pm 0.005^{* *}$ & $71.3 \pm 1.0^{* *}$ & $0.183 \pm 0.006^{* *}$ \\
\hline GM1 $(200 \mathrm{ng} / \mathrm{mL})$ & $55.0 \pm 0.8^{* *}$ & $0.135 \pm 0.002^{* *}$ & $61.5 \pm 1.3^{* *}$ & $0.164 \pm 0.003^{* *}$ & $69.3 \pm 1.0^{* *}$ & $0.182 \pm 0.003^{* *}$ \\
\hline Negative control & $29.0 \pm 1.8$ & $0.124 \pm 0.001$ & $36.0 \pm 1.8$ & $0.118 \pm 0.001$ & $31.5 \pm 2.4$ & $0.117 \pm 0.003$ \\
\hline
\end{tabular}

$* \mathrm{P}<0.05$ vs EGF+bFGF (C) group, $* * \mathrm{P}<0.05$ vs negative control. bFGF $=$ basic fibroblast growth factor; EGF $=$ epidermal growth factor; MTT = 3-(4,5-dimethyl-2-thiazolyl)-2,5-diphenyl-2H-tetrazolium bromide.

\section{NSC count and viability under different NGF concentrations in medium lacking bFGF and EGF}

At days 4, 7, and 10, cell counts and MTT values were significantly reduced at all NGF concentrations $(25,50,100$, and $200 \mathrm{ng} / \mathrm{mL})$ compared with positive $(\mathrm{P}<0.05)$ but 
not negative $(\mathrm{P}>0.05)$ control cultures. This was also the case with GM1 $(100 \mathrm{ng} / \mathrm{mL})$ cotreatment (Table 4).

Table 4. Cell count and viability at days 4, 7, and 10 following neural growth factor administration in medium lacking basic fibroblast growth factor and epidermal growth factor $(\mathrm{N}=4$, data are reported as means \pm standard error).

\begin{tabular}{l|c|c|c|c|c|c}
\multirow{2}{*}{ Group } & \multicolumn{2}{|c|}{ Day 4} & \multicolumn{2}{c}{ Day 7} & \multicolumn{2}{c}{ Day 10 } \\
\cline { 2 - 7 } & Cell count & MTT value & Cell count & MTT value & Cell count & MTT value \\
\hline EGF+bFGF $(C)$ & $53.8 \pm 3.4$ & $0.136 \pm 0.005$ & $65.5 \pm 1.3$ & $0.169 \pm 0.002$ & $72.8 \pm 3.7$ & $0.178 \pm 0.002$ \\
\hline NGF $(25 \mathrm{ng} / \mathrm{mL})$ & $32.0 \pm 1.8^{*}$ & $0.123 \pm 0.002^{*}$ & $34.5 \pm 1.3^{*}$ & $0.123 \pm 0.002^{*}$ & $37.0 \pm 6.1^{*}$ & $0.119 \pm 0.002^{*}$ \\
\hline NGF $(50 \mathrm{ng} / \mathrm{mL})$ & $31.0 \pm 1.8^{*}$ & $0.122 \pm 0.003^{*}$ & $31.3 \pm 3.6^{*}$ & $0.118 \pm 0.002^{*}$ & $34.0 \pm 2.2^{*}$ & $0.115 \pm 0.003^{*}$ \\
\hline NGF $(100 \mathrm{ng} / \mathrm{mL})$ & $31.8 \pm 1.7^{*}$ & $0.122 \pm 0.002^{*}$ & $34.0 \pm 1.8^{*}$ & $0.118 \pm 0.001^{*}$ & $39.0 \pm 0.8^{*}$ & $0.115 \pm 0.002^{*}$ \\
\hline NGF $(200 \mathrm{ng} / \mathrm{mL})$ & $30.0 \pm 0.8^{*}$ & $0.122 \pm 0.001^{*}$ & $35.0 \pm 1.8^{*}$ & $0.116 \pm 0.003^{*}$ & $32.0 \pm 18^{*}$ & $0.117 \pm 0.002^{*}$ \\
\hline GM1+NGF & $31.3 \pm 1.7^{*}$ & $0.128 \pm 0.002^{*}$ & $47.5 \pm 1.3^{*}$ & $0.133 \pm 0.002^{*}$ & $49.0 \pm 2.6^{*}$ & $0.161 \pm 0.002^{*}$ \\
\hline Negative control & $29.0 \pm 1.8$ & $0.124 \pm 0.001$ & $36.0 \pm 1.8$ & $0.118 \pm 0.001$ & $31.5 \pm 2.4$ & $0.117 \pm 0.003$ \\
\hline
\end{tabular}

$* \mathrm{P}<0.05$ vs $\mathrm{EGF}+\mathrm{bFGF}(\mathrm{C})$ group. $\mathrm{NGF}=$ neural growth factor; $\mathrm{bFGF}=$ basic fibroblast growth factor; $\mathrm{EGF}=$ epidermal growth factor; MTT = 3-(4,5-dimethyl-2-thiazolyl)-2,5-diphenyl-2H-tetrazolium bromide.

\section{Nestin, NSE, and GFAP protein expression}

Compared to the control group, a high dose of GM1 (100 ng/mL) significantly upregulated nestin expression $(\mathrm{P}<0.05)$, but showed no notable effects on NSE and GFAP levels $(\mathrm{P}>0.05)$ at days 4 and 7 . Treatment with a high concentration of NGF $(100 \mathrm{ng} / \mathrm{mL})$ markedly promoted GFAP and NSE expression $(\mathrm{P}<0.05)$, but had no significant influence on nestin level (Figure 1, left). Quantitative data are displayed in Figure 2 (right).

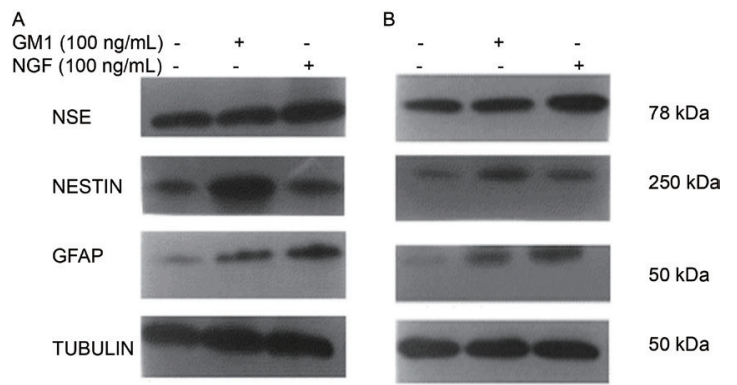

Figure 1. Western blots of nestin, neuron-specific enolase (NSE), and glial fibrillary acidic protein (GFAP) expression on days 4 and 7 after administration of ganglioside GM1 or neural growth factor (NGF). A. Expression of nestin, NSE, and GFAP on day 4 after administration of GM1 or NGF. B. Expression of nestin, NSE, and GFAP on day 7 after administration of GM1 or NGF.
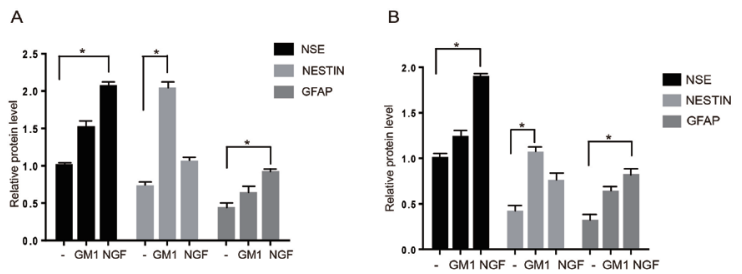

Figure 2. Quantitative data relating to relative nestin, neuron-specific enolase (NSE), and glial fibrillary acidic protein (GFAP) expression. A. Expression of nestin, NSE, and GFAP on day 4 after administration of ganglioside GM1 or neural growth factor (NGF). B. Expression of nestin, NSE, and GFAP on day 7 after administration of GM1 or NGF.

Genetics and Molecular Research 15 (3): gmr.15038376 


\section{DISCUSSION}

Timmer and Nikkhah (2012) described a novel strategy for intrastriatal dopaminergic cell transplantation, in which sequential "nest" grafting was shown to restore survival and behavior in a rat model of Parkinson's disease. This suggested that neurons play vital roles in human disease recovery. However, neurons in the mammalian central nervous system (CNS) are generated from early embryonic development until early postnatal stages, with few neurogenic zones remaining active in adults (Götz and Huttner, 2005; Paridaen and Huttner, 2014).

Reynolds and Weiss (1992) reported the successful generation of neurospheres, containing cells capable of self-replication and differentiation into neurons and glia, laying the foundations of NSC research. NSCs have subsequently become the focus of work on the development and regeneration of the CNS. For instance, NSC transplantation together with erythropoietin injection has been reported to positively affect axon regeneration in adult rats having suffered transected spinal cord injuries (Zhao et al., 2015). In addition, a combination of edaravone and NSC transplantation has been shown to repair injured spinal cords in a rat model (Song et al., 2015). Moreover, GM1 and NGF synergistically effect neurite regeneration, neurofilament protein upregulation, and stimulation of neuritogenesis (Bolsover, 2005).

NSCs, whose transplantation may realize CNS repair, are capable of differentiation into neurons and glial cells (Tarasenko et al., 2004). bFGF, EGF, neurotrophic factors, leukemia inhibitory factor, platelet-derived growth factor, IGFs, and various other growth factors are reported to exert different effects on NSC proliferation and differentiation (Huang et al., 2013). The current study aimed to investigate the effects of GM1 and NGF on NSC proliferation and differentiation to provide further data informing clinician guidelines for the efficient treatment of neurogenic disease.

We utilized serum-free medium to culture NSCs in each group, thus removing confounding factors that may have induced proliferation and/or differentiation. Our results indicated that a high concentration of GM1 promoted NSC proliferation in DMEM/F12 containing bFGF and EGF, as it did in that lacking these growth factors, but did not include differentiation.

The effect of the mitogens bFGF and EGF on NSCs has been confirmed in vitro (Tarasenko et al., 2004; Huang et al., 2013), and the present study demonstrated that GM1 plays a similar role. Consistent with results of cell counts and MTT assays, western blotting showed that at days 4 and 7, nestin protein level was significantly upregulated in GM1-treated cultures. Two issues remain to be resolved, namely, the means by which GM1 upregulates nestin expression, and the biochemical pathways GM1 depends upon to exhibit the effects on cell count and viability. We will carry out further studies to investigate these aspects in the near future.

Neurotrophic factors also play important roles in neural cell differentiation, proliferation, and survival. As the first discovered neurotrophic factor, NGF is one of the most important biological molecules, and is indispensable in the development and function of the nervous system (Zhang et al., 2011). NGF also promotes NSCs to differentiate into neurons and astrocytes (Lachyankar et al., 1997; Levenberg et al., 2005; Nakajima et al., 2007; Choi et al., 2008), a process brought about by the down-regulation of ATF5 expression and upregulation of TIMP-2 (Angelastro et al., 2003; Jaworski and Pérez-Martínez, 2006). Our study demonstrated that NGF failed to promote NSC proliferation based on cell counts and MTT assays, but clearly induced NSC differentiation, manifested as upregulated levels of both GFAP and NSE proteins at days 4 and 7, consistent with previous reports (Lachyankar et al., 1997; Levenberg et al., 2005; Nakajima et al., 2007; Choi et al., 2008).

Genetics and Molecular Research 15 (3): gmr.15038376 
In vivo experiments have revealed that GM1 and NGF may have a synergistic effect on NSCs. GM1 increases the trophic effects of NGF, and decreases cell death (Dreyfus et al., 1998; Huang et al., 2009).

Therefore, in future clinical application of NSC transplantation, drug administration can be carried out in stages. For the first stage comprising in vitro amplification of NSCs, GM1 may be used at a concentration of $25-200 \mathrm{ng} / \mathrm{mL}$. In the second stage consisting of directional differentiation of NSCs to obtain neurons and glia, NGF would be appropriate, at a recommended concentration between 10 and $200 \mathrm{ng} / \mathrm{mL}$.

We may draw the conclusion that GM1 and NGF promote NSC proliferation and differentiation, respectively, in a dose-dependent manner. Our results represent an important goal for clinicians, by whom they may be used to choose appropriate therapeutic strategies for patients.

\section{Conflicts of interest}

The authors declare no conflict of interest.

\section{REFERENCES}

Angelastro JM, Ignatova TN, Kukekov VG, Steindler DA, et al. (2003). Regulated expression of ATF5 is required for the progression of neural progenitor cells to neurons. J. Neurosci. 23: 4590-4600.

Bolsover SR (2005). Calcium signalling in growth cone migration. Cell Calcium 37: 395-402. http://dx.doi.org/10.1016/j. ceca.2005.01.007

Burney MJ, Johnston C, Wong KY, Teng SW, et al. (2013). An epigenetic signature of developmental potential in neural stem cells and early neurons. Stem Cells 31: 1868-1880. http://dx.doi.org/10.1002/stem.1431

Chen SQ, Cai Q, Shen YY, Cai XY, et al. (2014). Combined use of NGF/BDNF/bFGF promotes proliferation and differentiation of neural stem cells in vitro. Int. J. Dev. Neurosci. 38: 74-78. http://dx.doi.org/10.1016/j. ijdevneu.2014.08.002

Choi KC, Yoo DS, Cho KS, Huh PW, et al. (2008). Effect of single growth factor and growth factor combinations on differentiation of neural stem cells. J. Korean Neurosurg. Soc. 44: 375-381. http://dx.doi.org/10.3340/ jkns.2008.44.6.375

Corti S, Locatelli F, Strazzer S, Guglieri M, et al. (2003). Neuronal generation from somatic stem cells: current knowledge and perspectives on the treatment of acquired and degenerative central nervous system disorders. Curr. Gene Ther. 3: 247-272.http://dx.doi.org/10.2174/1566523034578375

Dreyfus H, Sahel J, Heidinger V, Mohand-Said S, et al. (1998). Gangliosides and neurotrophic growth factors in the retina. Molecular interactions and applications as neuroprotective agents. Ann. N. Y. Acad. Sci. 845: 240-252. http://dx.doi. org/10.1111/j.1749-6632.1998.tb09677.x

Faigle R and Song H (2013). Signaling mechanisms regulating adult neural stem cells and neurogenesis. Biochim. Biophys. Acta 1830: 2435-2448. http://dx.doi.org/10.1016/j.bbagen.2012.09.002

Götz M and Huttner WB (2005). The cell biology of neurogenesis. Nat. Rev. Mol. Cell Biol. 6: 777-788. http://dx.doi. org $10.1038 / \mathrm{nrm} 1739$

Huang F, Dong X, Zhang L, Zhang X, et al. (2009). The neuroprotective effects of NGF combined with GM1 on injured spinal cord neurons in vitro. Brain Res. Bull. 79: 85-88. http://dx.doi.org/10.1016/j.brainresbull.2008.12.007

Huang F, Shen Q and Zhao J (2013). Growth and differentiation of neural stem cells in a three-dimensional collagen gel scaffold. Neural Regen. Res. 8: 313-319.

Itokazu Y, Kato-Negishi M, Nakatani Y, Ariga T, et al. (2013). Effects of amyloid $\beta$-peptides and gangliosides on mouse neural stem cells. Neurochem. Res. 38: 2019-2027.http://dx.doi.org/10.1007/s11064-013-1108-y

Jaworski DM and Pérez-Martínez L (2006). Tissue inhibitor of metalloproteinase-2 (TIMP-2) expression is regulated by multiple neural differentiation signals. J. Neurochem. 98: 234-247. http://dx.doi.org/10.1111/j.14714159.2006.03855.X

Ji R, Meng L, Jiang X, Cvm NK, et al. (2014). TAM receptors support neural stem cell survival, proliferation and neuronal differentiation. PLoS One 9: e115140.http://dx.doi.org/10.1371/journal.pone.0115140

Genetics and Molecular Research 15 (3): gmr.15038376 
Lachyankar MB, Condon PJ, Quesenberry PJ, Litofsky NS, et al. (1997). Embryonic precursor cells that express Trk receptors: induction of different cell fates by NGF, BDNF, NT-3, and CNTF. Exp. Neurol. 144: 350-360. http:// dx.doi.org/10.1006/exnr.1997.6434

Levenberg S, Burdick JA, Kraehenbuehl T and Langer R (2005). Neurotrophin-induced differentiation of human embryonic stem cells on three-dimensional polymeric scaffolds. Tissue Eng. 11: 506-512. http://dx.doi.org/10.1089/ ten.2005.11.506

Ming GL and Song H (2011). Adult neurogenesis in the mammalian brain: significant answers and significant questions. Neuron 70: 687-702.http://dx.doi.org/10.1016/j.neuron.2011.05.001

Nakajima M, Ishimuro T, Kato K, Ko IK, et al. (2007). Combinatorial protein display for the cell-based screening of biomaterials that direct neural stem cell differentiation. Biomaterials 28: 1048-1060. http://dx.doi.org/10.1016/j. biomaterials.2006.10.004

Ourednik V, Ourednik J, Park KI, Teng YD, et al. (2000). Neural stem cells are uniquely suited for cell replacement and gene therapy in the CNS. Novartis Found. Symp. 231: 242-262; discussion 262-269, 302-306.

Paridaen JT and Huttner WB (2014). Neurogenesis during development of the vertebrate central nervous system. EMBO Rep. 15: 351-364.http://dx.doi.org/10.1002/embr.201438447

Reynolds BA and Weiss S (1992). Generation of neurons and astrocytes from isolated cells of the adult mammalian central nervous system. Science 255: 1707-1710. http://dx.doi.org/10.1126/science.1553558

Song YY, Peng CG and Ye XB (2015). Combination of edaravone and neural stem cell transplantation repairs injured spinal cord in rats. Genet. Mol. Res. 14: 19136-19143. http://dx.doi.org/10.4238/2015.December.29.23

Tarasenko YI, Yu Y, Jordan PM, Bottenstein J, et al. (2004). Effect of growth factors on proliferation and phenotypic differentiation of human fetal neural stem cells. J. Neurosci. Res. 78: 625-636. http://dx.doi.org/10.1002/jnr.20316

Timmer M and Nikkhah G (2012). A novel strategy for intrastriatal dopaminergic cell transplantation: sequential "nest" grafting influences survival and behavioral recovery in a rat model of Parkinson's disease. Exp. Cell Res. 318: 25312542. http://dx.doi.org/10.1016/j.yexcr.2012.08.002

Urbán N and Guillemot F (2014). Neurogenesis in the embryonic and adult brain: same regulators, different roles. Front. Cell. Neurosci. 8: 396.

Zhang L, Jiang H and Hu Z (2011). Concentration-dependent effect of nerve growth factor on cell fate determination of neural progenitors. Stem Cells Dev. 20: 1723-1731.http://dx.doi.org/10.1089/scd.2010.0370

Zhao Y, Zuo Y, Wang XL, Huo HJ, et al. (2015). Effect of neural stem cell transplantation combined with erythropoietin injection on axon regeneration in adult rats with transected spinal cord injury. Genet. Mol. Res. 14: 17799-17808. http://dx.doi.org/10.4238/2015.December.22.4

Genetics and Molecular Research 15 (3): gmr.15038376 